\title{
Histopathological alterations in the intestine of whitefish (Coregonus sp.) larvae reared on zooplankton from Lake Constance
}

\author{
Reiner Eckmann
}

Limnological Institute, University of Constance, P.O.Box 5560, D-7750 Konstanz, Federal Republic of Germany

\begin{abstract}
Coregonid larvae were found to suffer high mortality during the first days of feeding when reared on live zooplankton from their natural habitat. Histological studies on 7,13 , and $20 \mathrm{~d}$ old larvae suggested that these losses were caused by pathological alterations in the larvae's intestine. The symptoms observed include epithelial hyperplasia, dysplasia, and complete intestinal epithelial necrosis. These changes are compared with the normal histological differentiation found in larvae reared on Artemia nauplii. It is concluded that some component of lake plankton acts as a stressor to the larvae's intestinal epithelium and provokes the histopathological alterations which finally lead to the larvae's death.
\end{abstract}

\section{INTRODUCTION}

Mortality during early life of fishes has been studied intensely both under natural and laboratory conditions. In natural habitats, the dependence of year-class strength on larval survival still remains unclear (May 1974) but the prime importance of adequate food supply for fish larvae at the end of the yolk-sac period is generally accepted (Shelbourne 1957, Blaxter \& Ehrlich 1974). Therefore, in rearing studies with freshwater and marine fish species, efforts were oriented towards appropriate live food organisms as initial food for the larvae (Blaxter 1968, Lasker et al. 1970, Styczynska-Jurewicz et al. 1979). Recently, survival and growth rates of artificially reared larvae have been shown to depend on the dietary value of the food organisms which is chiefly determined by their essential fatty acid content (Watanabe et al. 1983). The reasons for losses among larval fish reared on presumably adequate live food organisms have scarcely been investigated however.

The present paper reports a case of high mortality among larval coregonids reared on live zooplankton from their natural habitat. Coregonids are the predominant zooplankton consumers in subalpine lakes. As they are of considerable commercial value, whitefish stocks in Lake Constance are routinely promoted by artificial incubation and by rearing of larvae with live zooplankton in hatcheries (Nümann 1972). Though severe losses during the first days of feeding have been observed repeatedly, cases of early mortality have not been investigated histologically so far. This is also true for other fish species. The normal histological differentiation of their digestive system has often been studied in detail (Smallwood \& Smallwood 1931, Tanaka 1973, Govoni 1980, Mähr et al. 1983), while histopathologiCal aspects were studied in starving larvae only (Ehrlich et al. 1976, O'Connell 1976).

The present paper describes histological changes observed in the intestine of coregonid larvae suffering high mortalities during their first days of feeding. These pathological changes are compared with the normal development which was studied in larvae reared on Artemia nauplii. The significance of these findings for larval survival in the natural habitat as well as for rearing operations is discussed.

\section{MATERIAL AND METHODS}

Larvae of the pelagic spawning coregonid form (Coregonus lavaretus complex) from Lake Constance (Federal Republic of Germany) were obtained from a federal hatchery in March 1984. At the age of $2 \mathrm{~d}$ they were stocked at a density of 1000 individuals per $60 \mathrm{l}$ tank filled with tap water. Temperature was adjusted 
to $12{ }^{\circ} \mathrm{C}$ and water was exchanged at a rate of 0.5 to 1.1 $1 \mathrm{~min}^{-1}$. Oxygen saturation was always around $100 \%$ and no ammonia enrichment was detected. The aquaria were exposed to a $12 \mathrm{~h}$ photoperiod with 15 min dimmed light at both dawn and dusk. Aquaria were cleaned daily and dead larvae registered. The experiments lasted $30 \mathrm{~d}$.

Four groups of larvae were set up for this experiment, 2 replicate groups were fed with zooplankton, 1 group was fed with Artemia nauplii, and the fourth group served as starving control. Zooplankton was collected daily in Lake Constance-Obersee (the large, mesotrophic basin of the lake) near the island of Mainau with a plankton net of $200 \mu \mathrm{m}$ mesh size. After separating the largest individuals by a $1000 \mu \mathrm{m}$ sieve, plankton was added to the aquaria so that the larvae could feed ad libitum. Plankton was mainly composed of Cyclops vicinus copepodites and adults and some C. abyssorum. These 2 species amounted to about 80 to $90 \%$, while Mesocyclops leukarti, Eudiaptomus gracilis, Bosmina sp., and Daphnia sp. were less important (Eckmann et al. in press). Artemia nauplii were hatched from commercially available cysts originating from San Francisco Bay (USA). Every day a new batch of cysts was incubated and nauplii were used as food during the first day after hatching only. Nauplii were fed to the larvae 2 or 3 times a day in excess.

For histological purposes, samples of living larvae were taken weekly and preserved in $5 \%$ borax-buffered formalin. They were dehydrated in a graded series of alcohol and the entire specimens were embedded in glycol methacrylate (Kulzer/Friedrichsdorf, FRG). Transverse body sections of 2 to $4 \mu \mathrm{m}$ thickness were cut with a glass knife from the foregut and midgut region (Fig. 1). Sections were stained with $1 \%$ azure II/methylene blue or with Schiff's reagent.

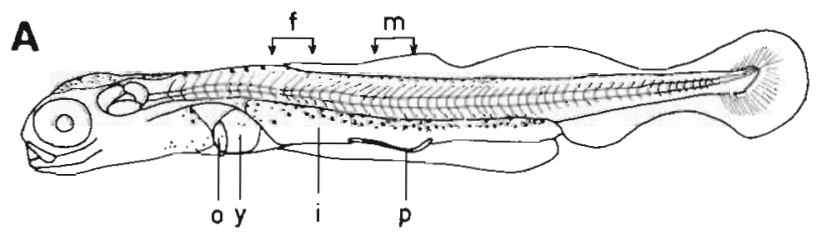

B

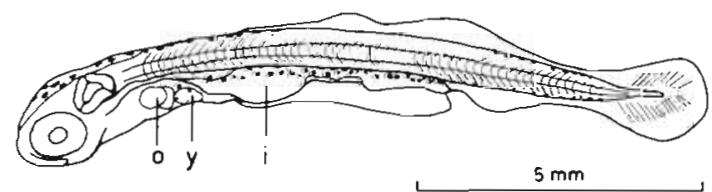

Fig. 1. Coregonus sp. Larvae, 13 d old. (A) Diet: Artemia nauplii; yolk still present, intestine completely filled, beginning differentiation of pelvic fins. (B) Diet: live zooplankton; yolk almost completely resorbed, intestine unevenly filled, body bent ventrally. o: oil globule; $y$ : yolk; i: intestine (constents dotted); f, m: foregut and midgut region from where histological sections were obtained
Table 1. Coregonus sp. Percentage cumulative mortality of larvae on Days 15 and 26 of the feeding experiments, and mean fresh and dry weight on Day 26. On Day 0, fresh weight was $6.0 \mathrm{mg}$ and dry weight $1.3 \mathrm{mg}$. Weight data were determined in samples of about 50 larvae each

\begin{tabular}{|lrrrr|}
\hline Food regime & $\begin{array}{c}\% \text { cumulative } \\
\text { mortality } \\
\text { (Day 15) }\end{array}$ & $\begin{array}{c}\text { Fresh } \\
\text { weight } \\
\text { (Day 26) }\end{array}$ & $\begin{array}{c}\text { Dry } \\
\text { weight } \\
\text { (mg) }\end{array}$ \\
\hline Live zooplankton & 43 & 88 & 8.2 & 1.0 \\
Live zooplankton & 50 & 90 & 7.1 & 0.8 \\
Artemia nauplii & 7 & 10 & 42.3 & 6.2 \\
Starvation & 11 & 93 & 4.9 & 0.5 \\
\hline
\end{tabular}

Photographs were taken only from sections stained by the former method. In total, the intestines of 36 larvae were examined histologically.

\section{RESULTS}

Within the first $15 \mathrm{~d}$, about $50 \%$ of the larvae fed with live zooplankton had died, while in the other 2 groups losses were negligible (Table 1). Early mortality in the starving control was caused by an accidental malfunctioning of the installations. Almost all dead larvae fed with zooplankton had their intestines filled, indicating that their deaths were related to zooplankton ingestion. Gut content analysis revealed that larvae fed mainly on copepodites and adults of Cyclops spp. Moribund larvae were easily recognized by their whitish, irregularly distributed intestinal contents and their ventrally curved bodies (Fig. 1).

During the following $11 \mathrm{~d}$, losses in all 4 groups were mainly due to starving larvae. More details on the differential mortality of feeding and starving larvae in these and additional experiments have been published in a previous paper (Eckmann et al. in press). At the age of $26 \mathrm{~d}$, the Artemia-fed larvae were already in the exponential growth phase while the few survivors among the zooplankton-fed larvae had barely maintained their initial weight (Table 1).

The alimentary canal of larval coregonids is a straight tube lined with a single layer of columnar cells from the foregut to the rectum. The nuclei of these epithelial cells are located basally and the cytoplasm in the apical part is granulated (Fig. 2). Goblet cells containing PAS-positive mucus are found in the epithelium of the buccal cavity and the esophagus of $3 \mathrm{~d}$ old larvae while in the intestine they are scarce. At the age of $7 \mathrm{~d}$, mucous secretion by the intestinal goblet cells is still low (Fig. 2a) but at the age of $13 \mathrm{~d}$ the number of goblet cells has increased and the entire intestinal epithelium is coated with a thick mucous layer (Fig. 2b). Finally, at 20 d, intestinal folds begin to 

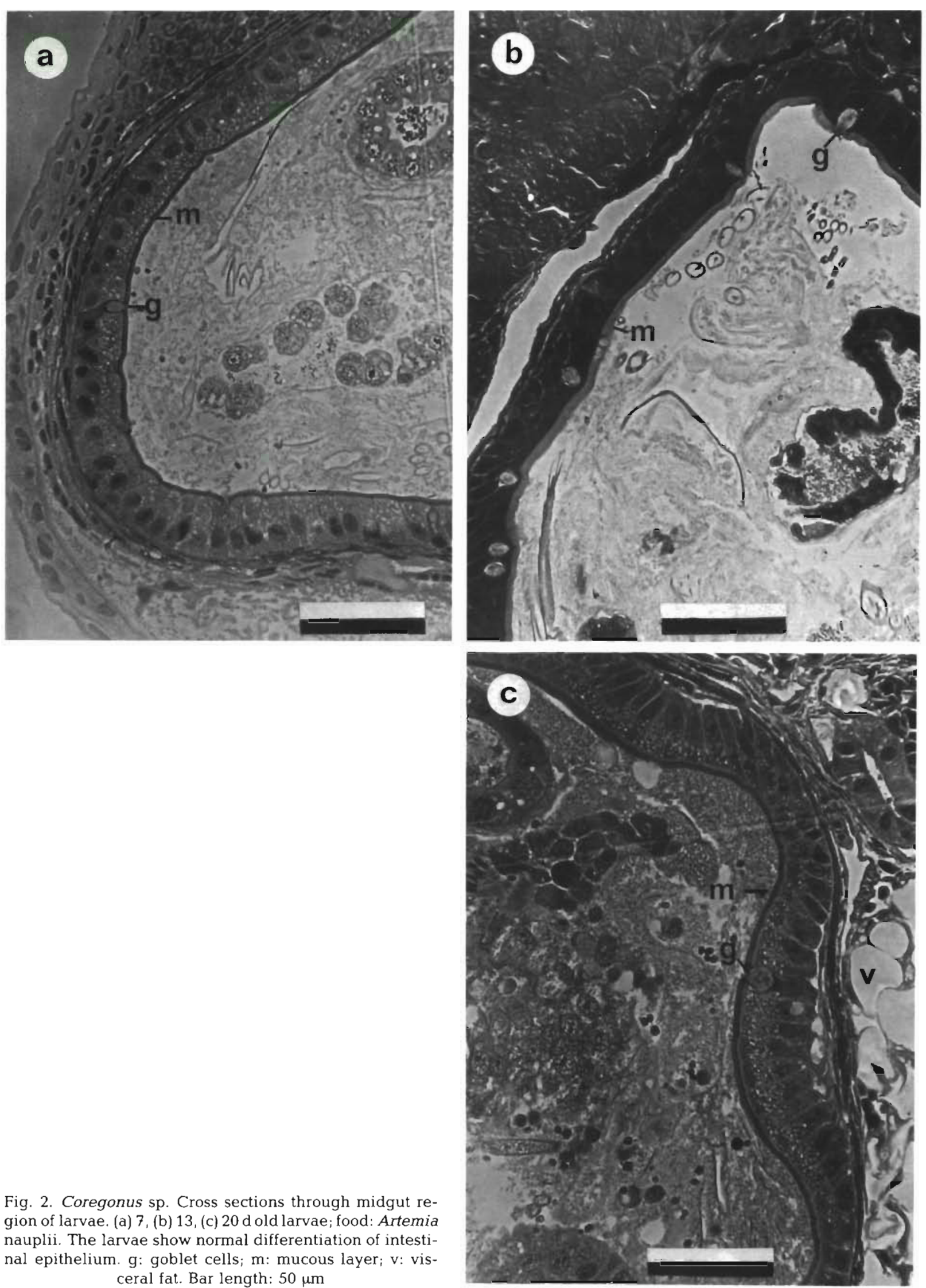

Fig. 2. Coregonus sp. Cross sections through midgut region of larvae. (a) 7, (b) 13, (c) 20 d old larvae; food: Artemia nauplii. The larvae show normal differentiation of intestinal epithelium. g: goblet cells; m: mucous layer; v: visceral fat. Bar length: $50 \mu \mathrm{m}$ 
form in the midgut region and visceral fat has already been deposited (Fig. 2c).

This normal intestinal differentiation was observed in Artemia-fed larvae. In contrast, zooplankton-fed larvae showed a variety of pathological changes. The first symptom observed in the midgut of a $7 \mathrm{~d}$ old larva is a polypoid hyperplasia of the intestinal epithelium (Fig. 3a). In the foregut of the same larva, the pathological changes are even more severe. Most of the cells are highly vacuolized and the epithelium is partly eroded (Fig. 3b). The nuclei of these necrotic cells are arranged in a completely disorganized manner. This form of epithelial erosion is therefore interpreted as the advanced pathological stage following epithelial hyperplasia.

Another pattern of pathological changes was observed in $13 \mathrm{~d}$ old larvae. The number of epithelial cells apparently remained unchanged but nearly all cells are vacuolized and many of them are extremely swollen (Fig. 4a). Some of the smallest vacuoles are faintly stained with PAS reagent but the majority of vacuoles appear empty. There are also groups of atrophied cells with dense cytoplasm. They are inter- preted as remnants of cells whose vacuolized apical parts were sloughed off into the intestinal lumen. The term 'dysplasia' is proposed to describe this atypical appearance of the epithelium. Different degrees of dysplasia were also observed in $20 \mathrm{~d}$ old larvae. At this time, the majority of losses had already occurred. It is therefore assumed that slight forms of intestinal dysplasia are reversible and that coregonid larvae might survive this pathological process. More severe forms of dysplasia are followed by epithelial erosion. In this case, cell membranes disintegrate, karyolysis takes place, and cell fragments or even complete groups of necrotic cells are scaled off the connective tissue (Fig. 4 b). Complete epithelial erosion (Fig. 4c) is considered the ultimate phase just prior to the larva's death.

\section{DISCUSSION}

The present study shows that the histological differentiation of the intestinal epithelium in the foregut and midgut of Coregonus larvae is seriously disturbed when they are fed an excess ration of zooplankton from
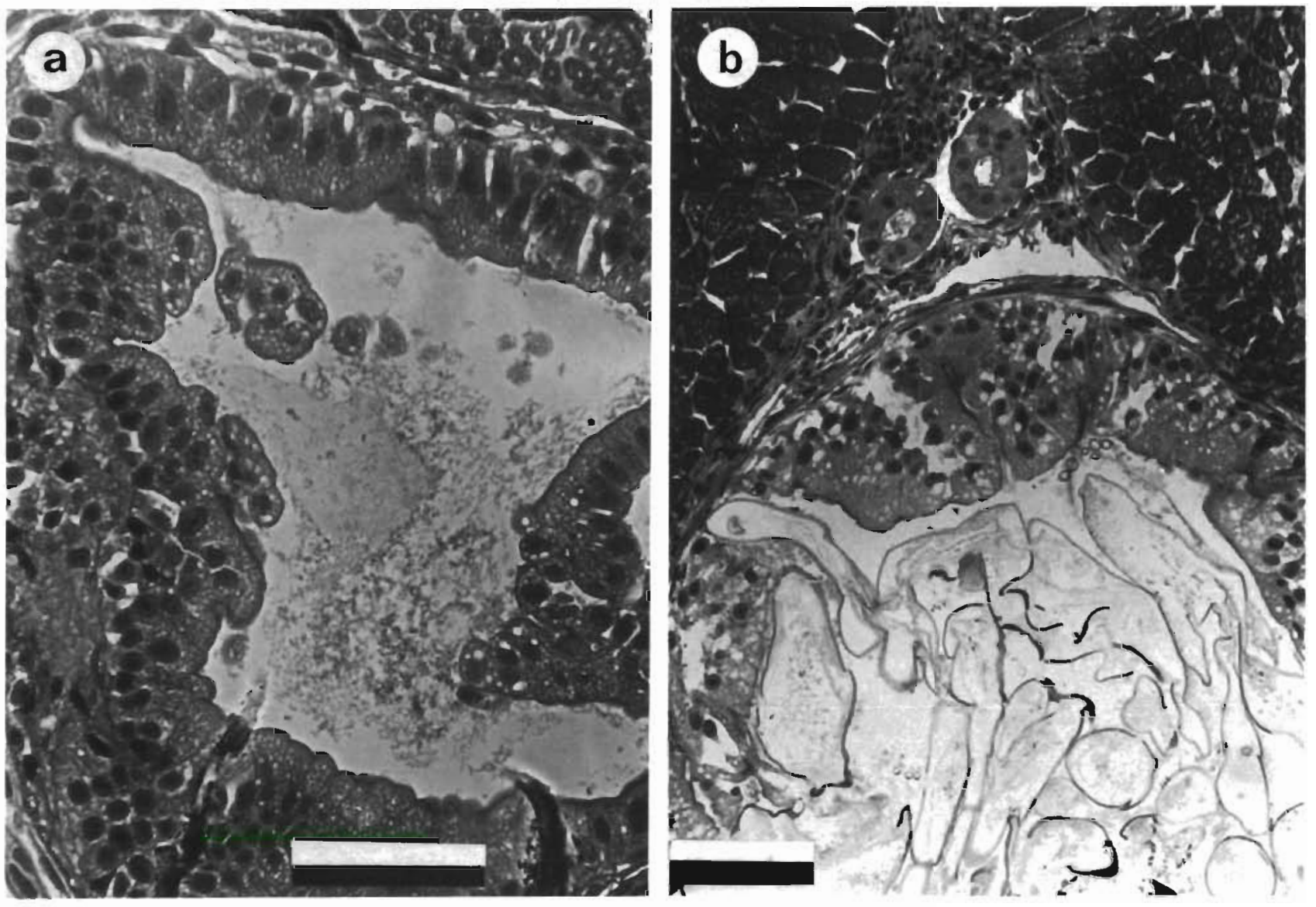

Fig. 3. Coregonus sp. Cross sections of a $7 \mathrm{~d}$ old larva fed zooplankton. (a) Polypoid hyperplasia in midgut; (b) necrotic hyperplasia in foregut region. Bar: $50 \mu \mathrm{m}$ 

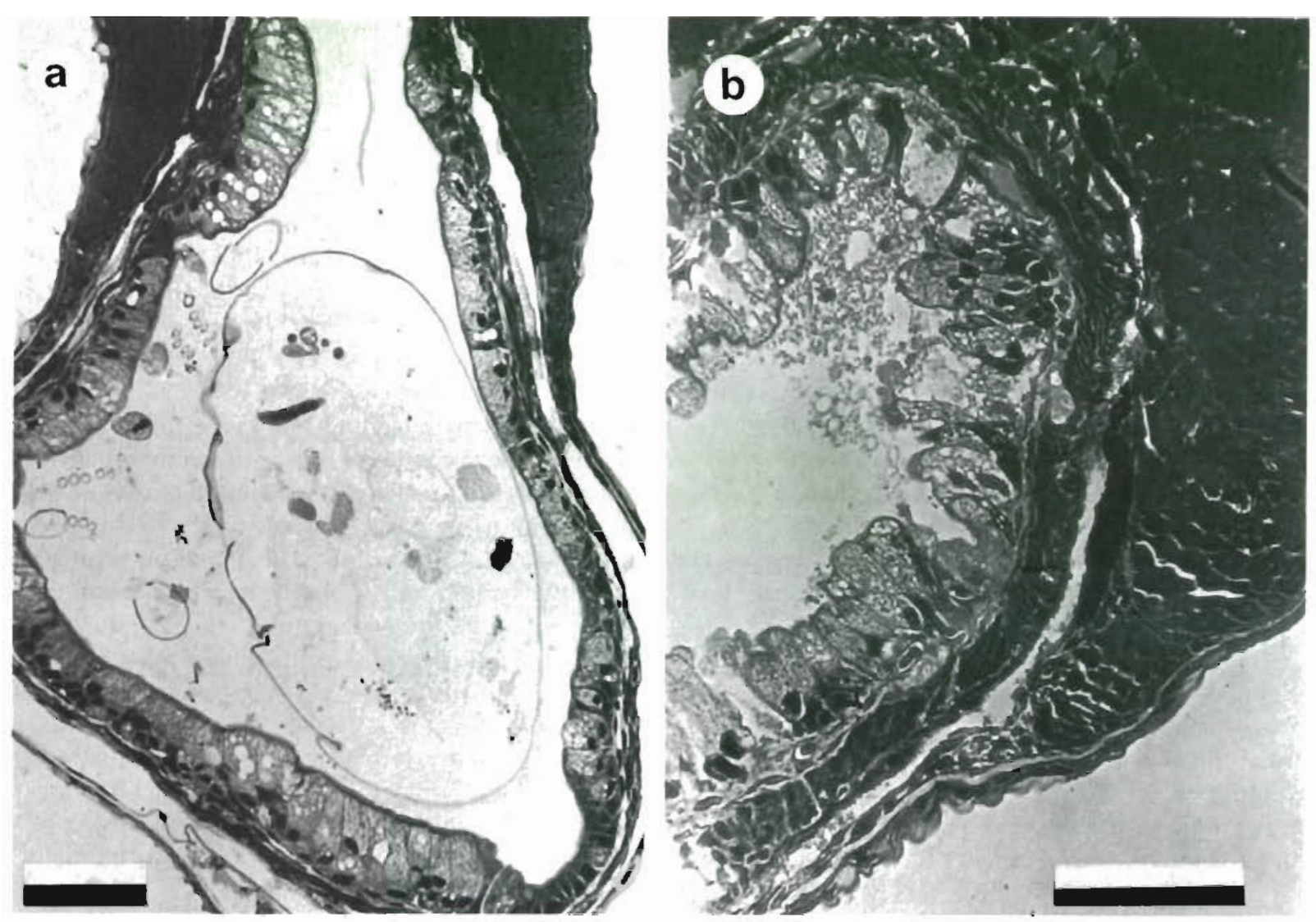

Fig. 4. Coregonus sp. Cross sections of 13 d old larvae fed zooplankton. (a) Dysplasia in foregut; (b) necrosis in midgut region; (c) complete intestinal necrosis. Bar: $50 \mu \mathrm{m}$

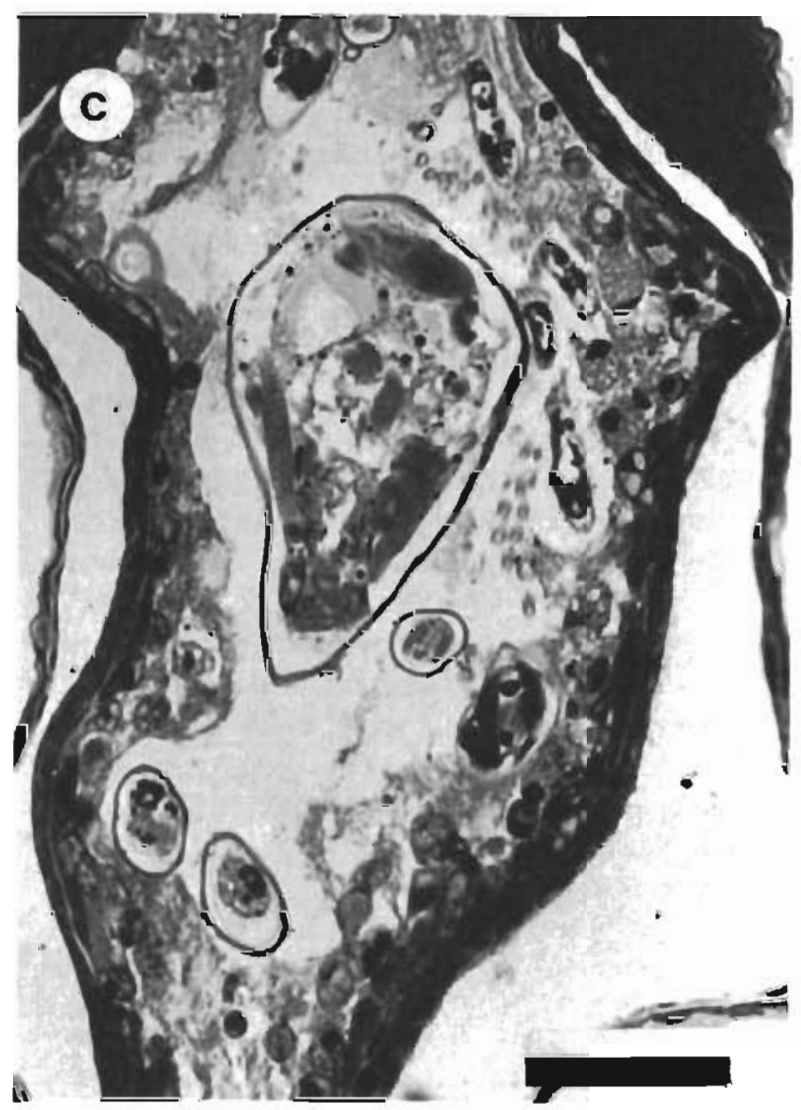


Lake Constance-Obersee. It is further concluded that these histopathological changes caused the heavy losses during the first days of feeding.

Two histological symptoms could be distinguished: intestinal hyperplasia and dysplasia. Both epithelial alterations are regarded as defense mechanisms of the organism against a stressor present in the zooplankton. This interpretation is supported by observations on surviving larvae which showed only moderate forms of intestinal dysplasia. However, in many cases the defense reactions of the larvae were insufficient and epithelial erosion occurred. It remains unclear at the moment whether minor intestinal erosions are reversible in coregonid larvae. But the severe forms of erosion (Fig. 4b) have to be considered as lethal for young larvae.

When discussing the possible nature of the stressor (or stressors) present in the plankton, we must discriminate between acute mortality recorded in the present experiments and larval mortality due to dietary deficiencies. The latter has been described repeatedly in various fish species. They could not be reared successfully on certain prey organisms. The rotifer Brachionus plicatilis, for example, which is widely used as initial diet for small fish larvae, frequently provoked sudden heavy losses of larval fish. It was found that by culturing the rotifers with yeast and marine Chlorella their dietary value was improved via their essential fatty-acid content. Mortality of fish larvae could thus be prevented (Watanabe et al. 1983).

Nauplii of the brine shrimp Artemia are employed worldwide for rearing freshwater and marine fish larvae (e.g. Sorgeloos 1980). Numerous studies have been undertaken to compare the dietary value of Artemia nauplii hatched from cysts of different geographical origin (e.g. Beck et al. 1980, Klein-Mac Phee et al. 1982). There is sufficient evidence now to conclude that it is the class of essential fatty acid contained in Artemia which determines its dietary value for fish larvae (Watanabe et al. 1983). It must be emphasized here that in all those rearing experiments where cultured rotifers, Artemia nauplii, and mixed zooplankton were employed, losses occurred later than in the starving controls. In the present study the pattern was just the opposite. Therefore, the deficit of some essential factor in the zooplankton can be excluded as causative agent for the early losses observed here. Additional observations on starving larvae support this conclusion. Their intestinal epithelium was clearly atrophied after 2 wk of starvation, but hyperplasia or dysplasia were never observed in these larvae. Further, pesticides and heavy metals have already been excluded as causes of the larvae's death (Eckmann et al. in press).

The species composition of zooplankton in Lake Constance-Obersee has changed since the 1950 s du- ring the course of eutrophication (Einsle 1983) but no major changes were recorded in recent years. Unfortunately, no studies on the rearing of whitefish larvae with lake plankton have been conducted during the last decades. Therefore it remains questionable whether the heavy losses observed here arise from changes in plankton composition or whether another, perhaps recent, phenomenon is involved.

Degenerative changes in the gastrointestinal tract have been described in elvers by Willemse et al. (1984) and in eels by Peters (1982). In the first case, frequent confrontation between densely stocked elvers was the stressor which provoked the pathological changes, while in the second case it was the permanent conflict for social dominance between pairs of eels. In the present study however, social stress is irrelevant since firstly, stocking densities and hence encounter rates were the same for all 4 groups of larvae, and secondly, there is no rank order among larval coregonids.

Ahne \& Thomsen (1985) isolated the VHS virus from adult Coregonus sp., a species not previously described as a host for VHS. Therefore, in spring of 1985 when heavy losses of larval coregonids occurred again (Rösch pers. comm.), samples of plankton and moribund larvae were examined for virus, bacterial, and parasite infections. Plankton and larvae were found to be virus negative and no parasites were observed, but Pseudomonas spp. were found in the gut contents. Since their incidence was low, they could hardly have been the cause for the pathology reported here. These results corroborate those of similar tests undertaken with 1984 plankton and larvae. At present, the stressor cannot yet be identified. It is suggested that the stressor is present in cyclopoid plankton from Lake Constance-Obersee or some component of it. Therefore, coregonid larvae which hatch in the lake might be affected by the stressor as well, and their fate during their first weeks of life needs to be studied with special emphasis on the histology of their digestive system.

From a practical point of view, the only presently available counter measure against heavy losses of whitefish larvae in hatcheries is th use of alternative food sources. This is already practised in some hatcheries where suitable plankton from other lakes is provided. Another possibility, the rearing of coregonids on dry food (Rösch \& Dabrowski in press) emerged recently.

Acknowledgements. This research was supported by the 'Deutsche Forschungsgemeinschaft' Grant No. Ti 115/14-1. R. Hoffmann and $W$. Ahne, Munich, kindly performed the tests for virus, bacterial, and parasite infections. The author wishes to thank Dr. G. Peters, Hamburg, and 3 anonymous referees for many helpful comments on this manuscript. 


\section{LITERATURE CITED}

Ahne, W., Thomsen, I (1985). Occurrence of VHS virus in wild white fish (Coregonus sp.). Zbl. Vet. Med. B., 32: $73-75$

Beck, A. D., Bengtson, D. A., Howell, W. H (1980). Interndtional study on Artemia. V.Nutritional value of five geographical strains of Artemia: effects on survival and growth of larval Atlantic silverside Menidia menidia. In: Persoone, G., Sorgeloos, P., Roels, O., Jaspers, E. (ed.) The brine shrimp Artemia. Universa Press, Wetteren, Belgium, p. $249-259$

Blaxter, J. H. S. (1968). Rearing herring larvae to metamorphosis and beyond. J. mar biol. Ass. U. K. 48: 17-28

Blaxter, J. H. S., Ehrlich, K. F. (1974). Changes in behaviour during starvation of herring and plaice larvae. In: Blaxter, J. H. S. (ed.) The early life history of fish. Springer, Heidelberg, New York, p. 575-588

Eckmann, R., Rösch, R., Ortlepp, J., Kleifeld, G. (in press). Survival and growth of coregonid larvae from Lake Constance fed on zooplankton of different origin. Arch. Hydrobiol., Suppl. Ergebn. Limnol.

Ehrlich, K. F., Blaxter, J. H. S., Pemberton, R. (1976). Morphological and histological changes during the growth and starvation of herring and plaice larvae. Mar. Biol. 35: $105-118$

Einsle, U. (1983). Long-term changes in planktonic associations of crustaceans in Lake Constance and adjacent waters and their effects on competitive situations. Hydrobiologia 106: 127-134

Govoni, J. J. (1980). Morphological, histological and functional aspects of alimentary canal and associated organ development in larval Leiostomus xanthurus. Rev. Can. Biol. 39: 69-80

Klein-MacPhee, G., Howell, W. H., Beck, A. D. (1982). Comparison of a reference strain and four geographical strains of Artemia as food for winter flounder (Pseudopleuronectes americanus) larvae. Aquaculture 29: $279-288$

Lasker, R., Feder, H. M., Theilacker, G. H., May, R. C. (1970). Feeding, growth, and survival of Engraulis mordax larvae reared in the laboratory. Mar Biol. 5: 345-353

Mähr, K., Grabner, M., Hofer, R., Moser, H. (1983). Histologi- cal and physiological development of the stomach in Coregonus sp. Arch. Hydrobiol. 98: 344-353

May, R. C. (1974). Larval mortality in marıne fishes and the critical period concept. In: Blaxter, J. H. S. (ed.) The early life history of fish. Springer, Heidelberg, New York, p 3-13

Nümann, W (1972). The Bodensee: effects of exploitation and eutrophication on the salmonid community. J. Fish. Res. Bd Can. 29: 833-847

O'Connell, C. P. (1976). Histological criteria for diagnosing the starving condition in the early post-yolk sac larvae of the northern anchovy, Engraulis mordax, Girard. J. exp. mar. Biol. Ecol. 25: 285-312

Peters, G. (1982). The effect of stress on the stomach of the European eel Anguilla anguilla L. J. Fish Biol. 21. 497-512

Rösch, R., Dabrowski, K. (in press). Tests of artificial food for larvae of Coregonus lavaretus from Lake Constance. Arch. Hydrobiol., Suppl. Ergebn. Limnol.

Shelbourne, J. E. (1957). The feeding and condition of plaice larvae in good and bad plankton patches. J. mar. biol. Ass. U. K. 36: 539-552

Smallwood, W. M., Smallwood, M. L. (1931). The development of the carp, Cyprinus carpio. I. The larval life of the carp with special reference to the development of the intestinal canal. J. Morph. 52: 217-231

Sorgeloos, P. (1980). The use of the brine shrimp Artemia in aquaculture. In: Persoone, G., Sorgeloos, P., Roels, O., Jaspers, E. (ed.) The brine shrimp Artemia. Universa Press, Wetteren, Belgium, p. 25-46

Styczynska-Jurewicz, E., Backiel, T., Jaspers, E., Persoone, G. (ed) (1979). Cultivation of fish fry and its live food. European Mariculture Society, Spec. Publ. No. 4: 1-534

Tanaka, M. (1973). Studies on the structure and function of the digestive system of teleost larvae. Ph. D. thesis, Faculty of Agriculture, Kyoto University, Japan

Watanabe, T., Kitajima, C., Fujjta, S. (1983). Nutritional values of live organisms used in Japan for mass propagation of fish: a review. Aquaculture 34: 115-143

Willemse, J. J., Markus-Silvis, L., Ketting, G. H. (1984). Morphological effects of stress in cultured elvers, Anguilla anguilla (L.). Aquaculture 36: 193-201 